\title{
Metastatic Angiosarcoma of the Thyroid Gland: A Case Report
}

\section{Tiroid Bezinin Metastatik Anjiosarkomu: Olgu Sunumu}

\author{
Umut Demirci ${ }^{1}$, Ayş̧e Demirci ${ }^{1}$, Uğur Coşkun ${ }^{2}$, Gülnihal Tufan $^{3}$, Ömür Ataoğlu ${ }^{4}$, Bahar G. Demirci $^{5}$, \\ Özgür Akdemir ${ }^{6}$, Mustafa Benekli², Süleyman Büyükberber ${ }^{2}$ \\ ${ }^{1}$ Dr. A. Y. Ankara Onkoloji Eğitim Ve Araştırma Hastanesi, Tıbbi Onkoloji Kliniği, Ankara, Türkiye \\ ${ }^{2}$ Gazi Üniversitesi Tıp Fakültesi, Tıbbi Onkoloji Bilim Dalı, Ankara \\ ${ }^{3}$ Recep Tayyip Erdoğan Üniversitesi Eğitim Ve Araştırma Hastanesi, Tıbbi Onkoloji Bölümü, Rize \\ ${ }^{4}$ Mikro-pat Patoloji Laboratuarları, Ankara, Türkiye \\ ${ }^{5}$ Başkent Üniversitesi Tıp Fakültesi, Nefroloji Bilim Dalı, Ankara, Türkiye \\ ${ }^{6}$ Gazi Üniversitesi Tıp Fakültesi, Nükleer Tıp Bilim Dalı, Ankara, Türkiye
}

DOI: $10.5505 /$ aot.2012.21931

\section{ÖZET}

Tiroid anjiosarkomu nadir görülen bir yumuşak doku sarkomudur. Biz burada genel semptomlarla ve eritrosit sedimantasyon hızı yüksekliği ile tanı alan metastatik tiroid anjiosarkomlu bir hastayı sunduk. Tiroid anjiosarkomunun prognozu kötüdür ve yeni, etkin tedavi seçeneklerine ihtiyaç duyulmaktadır.

Anahtar Kelimeler: Tiroid neoplazm; Anjiyosarkom; Pozitron-emisyon

\section{ABSTRACT}

Thyroid angiosarcoma is an extraordinary soft tissue sarcoma. We described a patient with metastatic thyroid angiosarcoma who presented with constitutional sypmtoms and elevated erythrocyte sedimentation rate. The prognosis of thyroid angiosarcoma is poor and we need new effective treatment options.

Keywords: Thyroid neoplasms; Angiosarcoma; Positron-emission tomography

\section{Giriş}

Thyroid angiosarcoma is a very rare soft tissue sarcoma that arises from vessels (1). It is uncommon other than endemic iodine-deficient areas as European Alpine (2). Typical presentation is rapidly enlarging neck mass in elderly patients with or without goiter history (2). Males and females are affected equally. Recently it was classified as different from anaplastic carcinoma (3).

Histologically, the tumor has typically extensive areas of necrosis and hemorrhages. The tumor cells express vascular markers such as factor VIII, CD31, and CD34 (5,6). Prognostic factors are grade, size and location of the primary tumor. Although radical surgery combined with radiation therapy (RT) has been the standard treatment, adjuvant chemotherapy is also widely accepted. Angiosarcomas often metastasize to the regional lymph nodes and lungs thus prognosis is not favorable especially in advanced disease $(7,8)$. Here-in we described an extraordinary soft tissue sarcomametastatic thyroid angiosarcoma- patient who presented with constitutional symptoms and elevated erythrocyte sedimentation rate (ESR).

\section{Case Report}

A 64 year-old woman was directed to our department because of ESR as $90 \mathrm{~mm} / \mathrm{h}$ with abnormal weight loss in last two months. On physical examination, a fixed mass with $2 \mathrm{~cm}$ in diameter was detected in left thyroid lobe and thyroid gland was enlarged grade 2 . She had hypertension, goiter and newly diagnosed type 2 diabetes mellitus. There was no feature in her family history. Polyclonal gammopathy was detected in serum protein electrophoresis. However serum and urine immunofixation tests were normal. Ultrasonography showed $57 \times 36 \mathrm{~mm}$ nodule with calcifications in the right thyroid lobe, 7x6 $\mathrm{mm}$ diameter nodule in the left thyroid lobe, and reactive lymph nodes of which the greatest was measuring $13 \times 7 \mathrm{~mm}$ in right cervical chain. The fine needle aspiration biopsy showed poorly differantiated malignant epithelial tumor (anaplastic carcinoma or medullary carcinoma). Calcitonin 
level was within normal limits. Because of the clinical and pathological contradictory findings, total thyroidectomy was performed. Microscopic examination showed completely necrotic neoplastic mass with vascular structure and epithelioid-like cells. On immunohistochemical examination, tumor cells were stained strongly positive with CD34 which is characteristic for hemangiosarcoma (Fig. 1)

Positron emission tomographycomputerized tomography (PET/CT) was showed increased uptake in right jugular (Standartized uptake value maximum (SUVm): 7.2), mediastinal, bilateral hilar and paratracheal lymph nodes (SUVm: 3.8) and focal area in dome of the liver (SUVm: 4) (Fig. 2). There was no pathological uptake in nodular lesion in multiple milimetric nodules in bilateral lung parenchyma. IMA (ifosfamide $2500 \mathrm{mg} / \mathrm{m}^{2}$ on days $1-3$, mesna $2500 \mathrm{mg} / \mathrm{m}^{2}$ days $1-3$, doxorubicin $60 \mathrm{mg} / \mathrm{m}^{2}$ day 1 , repeated every 21 days) regimen was performed as palliative treatment, however after four cycles the disease progressed with multimetastatic sites. The patient died after 10 months of diagnosis without salvage treatment.
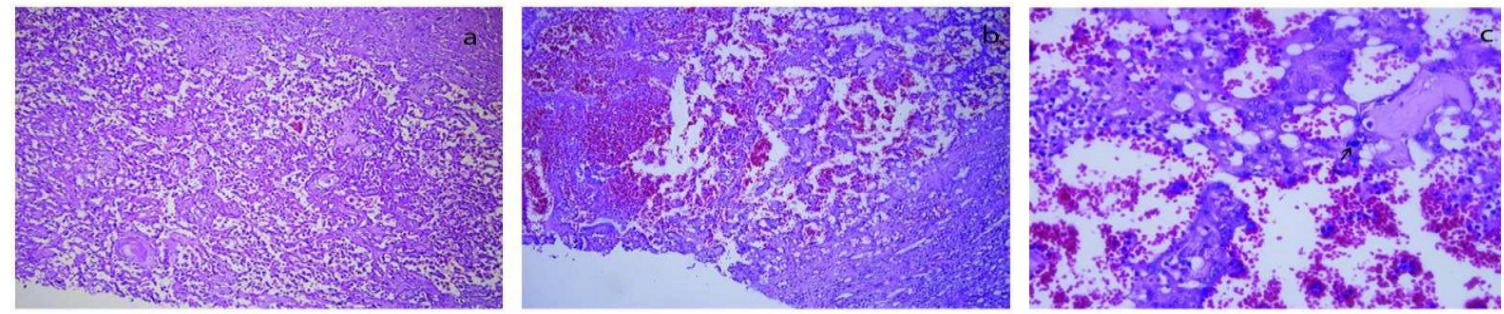

Figure 1. a) Tumoral devolepment characterized by anastomosed chanels, $\mathrm{H} \& \mathrm{E} \times 100, b)$ Cavernous pattern was filled by erythrocytes, $H \& E$ x200, c) Marked atypia, pleomorphism, and mitosis in epiteloid neoplastic cells that is CD34 positive, mitotic figure showed by arrow, H\&E x400

\section{Discussion}

Solid malignancies should be investigated especially in elderly who have constitutional symptoms, elevated ESR, and polyclonal gammapathy like in our case. Thyroid angiosarcomas constitute $2-10 \%$ of thyroid malignancies (2). Chronic goiter is an important predisposing risk factor for angiosarcoma. Lymphedema and radition are the risk factors for sarcomas additionally hemorrhage into a adenoma is thought to be a predisposing factor for thyroid angiosarcoma $(8,9)$. In a study, previous epithelial thyroid cancer was preexisted to thyroid angiosarcoma (10). Thyroid angiosarcoma is seen predominantly in elderly patients with a history of goiter and especially in iodine deficient areas, similar to our case. A few case reported from Turkey $(9,11)$.

Angiosarcomas consist of atypical epithelioid cells with eosinophilic cytoplasm lining vascular-like spaces besides usually large tumors which are hemorrhagic and easily mistaken for anaplastic thyroid cancer. Nearly $50 \%$ positivity can be detected in IHC

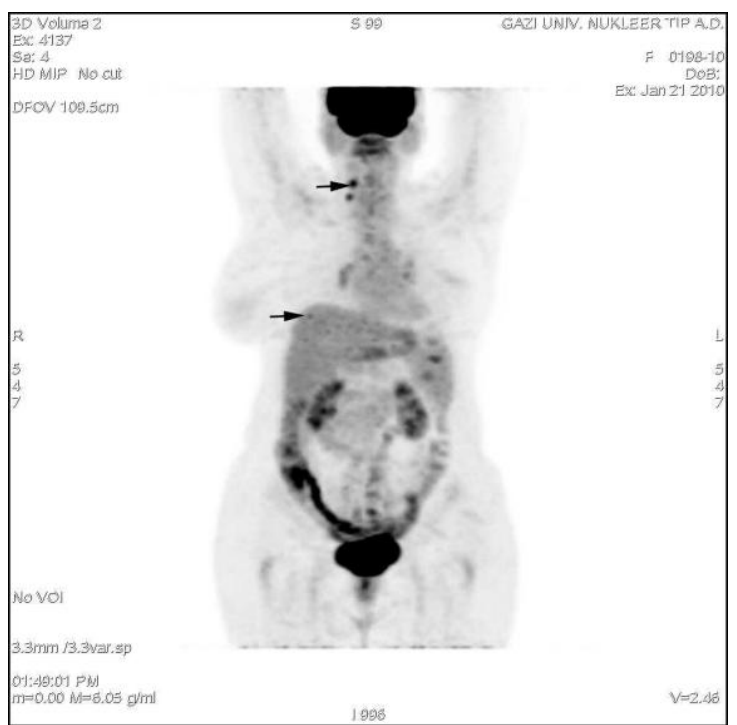

Figure 2: Distant metastases were detected in mediastinal lymph nodes (SUVm: 3.8), liver (SUVm: 4), and cervical lymph nodes (SUVm: 7.2) (PET/CT)

investigation of epithelioid angiosarcomas. We showed CD34 positivity, however we did not show positivity with cytokeratins. Endothelial markers, EMA and CD31 were recommended as markers to distinguish angiosarcoma from anaplastic carcinoma (4-6). 
Well-known prognostic factors of thyroid angiosarcomas are grade, size, and location. In a retrospective study of 43 patients with malignant vascular tumors, stage and tumor site were reported as the important prognostic factors (1). Maiorana et al. analyzed seven thyroid angiosarcoma cases and noted that the absence of extraglandular tumor spread at the time of surgery was associated with improved overall survival (4). Although surgery followed by RT has already been the standard approach, adjuvant chemotherapy is widely accepted. Prognosis is not favorable especially in metastatic disease $(7,8)$. Common sites for metastasis are regional lymph nodes and lungs, furthermore intestine and bone marrow metastases were also reported as case reports $(8,12)$. PET/CT can be used to characterize functional activity in thyroid angiosarcomas as other types of soft tissue sarcomas. In our case, distant metastases in lung and liver was detected by PET/CT.

Solid organ angiosarcomas often have poor prognosis. Only two patient had a long term survival in a series of 28 splenic angiosarcomas (12). Goh et al. indicated $33.3 \%$ 5-year overall survival for thyroid angiosarcoma (13). We administred palliative chemotherapy after total thyroidectomy. The disease progressed after four cycles and patient died after 10 months of diagnosis. In conclusion, the prognosis of thyroid angiosarcoma is poor and we need new effective treatment options.

\section{Conflict of Interest: None.}

\section{Kaynaklar}

1. Leowardi C, Hinz U, Hormann Y, et al. Malignant vascular tumors: clinical presentation, surgical therapy, and long-term prognosis. Ann Surg Oncol 2005;12:1090-01
2. Ryska A, Ludvíková M, Szépe P, Böör A. Epithelioid haemangiosarcoma of the thyroid gland.Report of six cases from a non-Alpine region. Histopathology 2004;44:40-6

3. Rosai J, Carcangiu ML, DeLellis RA. Tumors of the Thyroid Gland. Atlas of Tumor Pathology, Armed Forces Institute of Pathology, Washington, D.C. 1992

4. Maiorana A, Collina G, Cesinaro AM, Fano RA, Eusebi V. Epithelioid angiosarcoma of the thyroid. Clinicopathological analysis of seven cases from non-Alpine areas. Virchows Arch. 1996;429:131-7

5. Eusebi V. Angiosarcoma. In: DeLellis RA, Lloyd RV, Heitz PU, Eng C, editors. World health organisation classification of tumours. Pathology and genetics tumours of endocrine organs. Lyon, IARC Pres, 2004, pp 113-4

6. Cutlan RT, Greer JE, Wong FS, Eltorky M. Immunohistochemical characterization of thyroid gland angiomatoid tumors. Exp Mol Pathol 2000;69:159-64

7. Astl J, Dusková J, Límanová Z, Povýsil C, Kuchynková Z. Hemangiosarcoma of the thyroid gland. A case report. Neuro Endocrinol Lett 2000;21:213-6

8. Kalitova P, Plzak J, Kodet R, Astl J. Angiosarcoma of the thyroid. Eur Arch Otorhinolaryngol 2009;266:903-5

9. Dogan L, Karaman N, Irkkan C, Kucuk A, Atalay C. Angiosarcoma of the Thyroid and Regional Lymph Node Metastasis. J Clin Anal Med 2014;5:426-8

10. Meis-Kindblom JM, Kindblom LG. Angiosarcoma of soft tissue: a study of 80 cases. Am J Surg Pathol 1998;22:683-97

11. Yilmazlar T, Kirdak T, Adim S, Ozturk E, Yerci O. A case of hemangiosarcoma in thyroid with severe anemia due to bone marrow metastasis. Endocr $\mathbf{J}$ 2005;52:57-9

12. Neuhauser TS, Derringer GA, Thompson LD, et al. Splenic angiosarcoma: A clinicopathologic and immunophenotypic study of 28 cases. Mod Pathol 2000;13:978-87

13. Goh SG, Chuah KL, Goh HK, Chen YY. Two cases of epithelioid angiosarcoma involving the thyroid and a brief review of non-Alpine epithelioid angiosarcoma of the thyroid. Arch Pathol Lab Med $2003 ; 127: 70-3$ 